\title{
ANAESTHESIA FOR REPAIR OF CLEFT LIP AND PALATE IN INFANTS USING MODERATE HYPOTHERMIA
}

\author{
Chrustopher J. KRDUFF, M.B., B.CH., B.A.O." \\ GoRdON M. WYANT, F.F.A.R.C.S., D.A.(AM. BD.), D.A. (ENG.), F.A.C.A. ${ }^{*}$ \\ ROBERT H. DALE, F R.C.S (EDIN.), F.A.C.5.* *
}

Paediatric anaesthesia presents many interesting and challenging problems. The smaller the child, the greater are the anatomical and physiological differences between it and the adult, and the more is it necessary to modify anaesthetic techniques. Especially is this so in the presence of congenital malformations of the mouth. Some of the ma or considerations which apply to infant anaesthesia are: [1: The small tidal exchange renders more significant even a slight de jree of meclanical dead space in anaesthetic equipment. [2] The infant trac 3eobronchial tree has a narrow diameter with its greatest restriction at the cricoid ring rather than at the level of the cords (1). The wall of the endotracheal tube occupies a relatively greater proportion of the avalable airway thus increasing the resistance to breathing. Also a tube which easily passes the cords may impinge upon the cricoid ring Thrs can lead to subglothc oedema in the postopera ive period. [3] The heat-regulating mechanism of intants is still rather labile. Operative and postoperative hyperpyrexia is therefore common, heat Ioss being prevented by the sterile sheets which cover the child in a warm operating room. There is loss of body fluids by perspiration, undue fatigue, and in severe instances there may be convulsions. [4] Blood loss becomes very significant because of the small circulating volume. Haemorrhage must therefore be carefully controlled and blood tor transtusion should always be available for use if bleeding is excessive. On the other hand, it must be remembered that overtransfusion is a hazard, as the exact blood loss is difficult to estimate.

It has long been recognized that time is an importarit factor in the surgery of infants and that the margin of safety is generally small. In all methods of anaesthesia described it is emphasized that induction should be smooth and of short duration. It is generally agreed that anaesthesia should be maintaned at the lightest possible level; the baby will then awake almost as soon as surgery is completed and the feeding schedule will not be unduly interrupted. Endotracheal intubation in infants requires the skill of experience if hazards are to be avoided; but it is essential in surgery of the mouth and face, the advantages here outweighing the disadvantages and hazards $(2,3)$. The main advantages of intubation are to be found in the maintenance of a perfect airway with better control of tidal volume; there is thus good elimination of carbon dioxide with reduced tendency to capillary oozing. Intubation also allows a smoother and steadier level of anaesthesia to be maintained and will allow the anaesthetist to keep his equipment well clear of the surgical field.

"Department of Anaesthesia and "Department of Surgery (Plastic Service), University of Saskatchewan College of Medicine, and University Hospital, Saskatoon. Presented before the Western Division, Canadian Anaesthetusts' Society, April 5-7, 1956. 
Despite all the refinements of modern anaesthesia, the problem of bleeding in operations for cleft lip and palate has still remained with us. This is owing to the exceedingly rich blood supply of the tissues involved. Blood loss is poorly tolerated by small infants and may require transfusion. Even more important perhaps is the fact that bleeding will markedly prolong the duration of the operation, which should, if possible, always be completed within one hour from induction of anaesthesia. Undue prolongation may result in marked deterioration of the child's general condition.

In order to reduce bleeding we have of late started to use hypothermia of moderate degree by means of skin cooling. The apparatus used is the ThermoRite unit with cooling blankets. This unit allows for both cooling and heating of the blankets. The cooling apparatus is switched on betore the patient is brought up from the ward, so that the temperature of the blanket has reached approximately $70^{\circ} \mathrm{F}$ by the time the child is placed on it. A pillow is placed under the cooling blanket towards the head end of the table (Fig. 1). The operation is timed in such a way that it follows approximately 3 hours after the last feeding; in this way the feeding schedule is hardly interrupted at all. Atropine Sulphate is given intramuscularly on the ward 45 minutes before induction time. Induction is frequently preceded by basal anaesthesia with

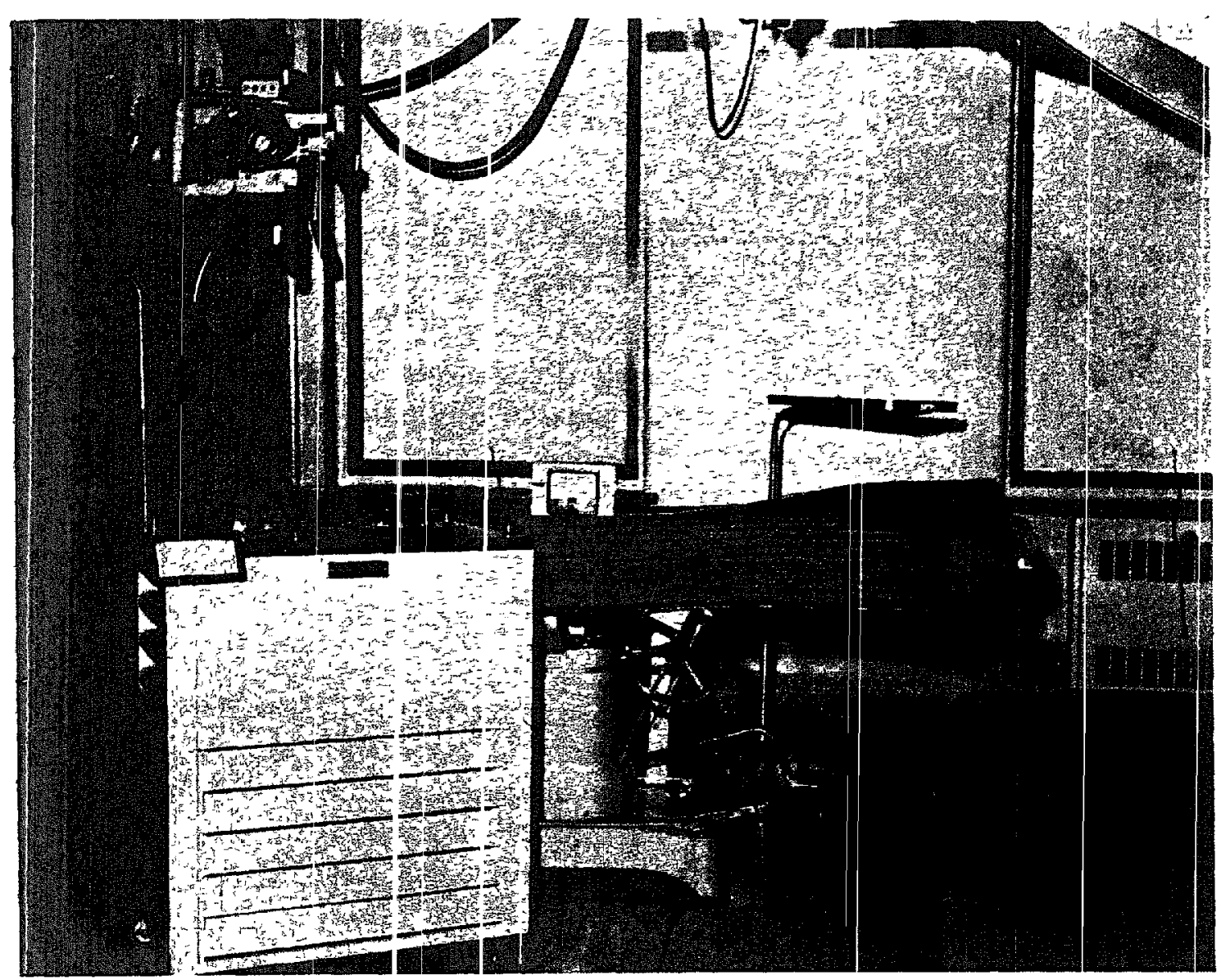

Figure 1. Cooling blankiet in position with pillow under the head end and electronic thermometer with rectal lend. 
rectal thiopental ( $1 \mathrm{Gm}$. per $50 \mathrm{lb}$. body weight as a 10 per cent solution). Anaesthesia itself is induced in one of two ways: either nitrous oxlde-oxygen followed by diethyl ether is used, or open drop divinyl ether is followed by diethyl ether and oxygen. When an adequate depth of anaesthesia is reached, intubation is performed by the oral route. One frequently finds that the laryngoscope sinks into the cleft lip and alveolus which results in difficulty in visualizing the larynx. A guard made of folded zinc oxide tape, placed across the cleft alveolus, will help to avoid this difficulty. Creat care must be taken at this point to avoid all trauma to soft tissues. The endotracheal tube is a plain black unreinforced Magill tube, and it is connected to a modified Ayre's T-piece (4).

As soon as the infant is intubated he is transferred to the operating table on which the hypothermia blanket has already been cooled and the lead of the electronic thermometer is placed in the rectum The head is then extended over the pillow at the end of the table. The surgeon now prepares the field of operation and begins to apply the drapes. For operation on the palate the modified Dott's gag is used, which steadies the tube in the mid-line without kinking (5).

A Mayo table is placed above the baby's trunk to keep the weight of the drapes off the body and allow free crrculation of air It also serves its original purpose as an instrument table and beneath it the anaesthetist has access to the baby (Fig. 2).

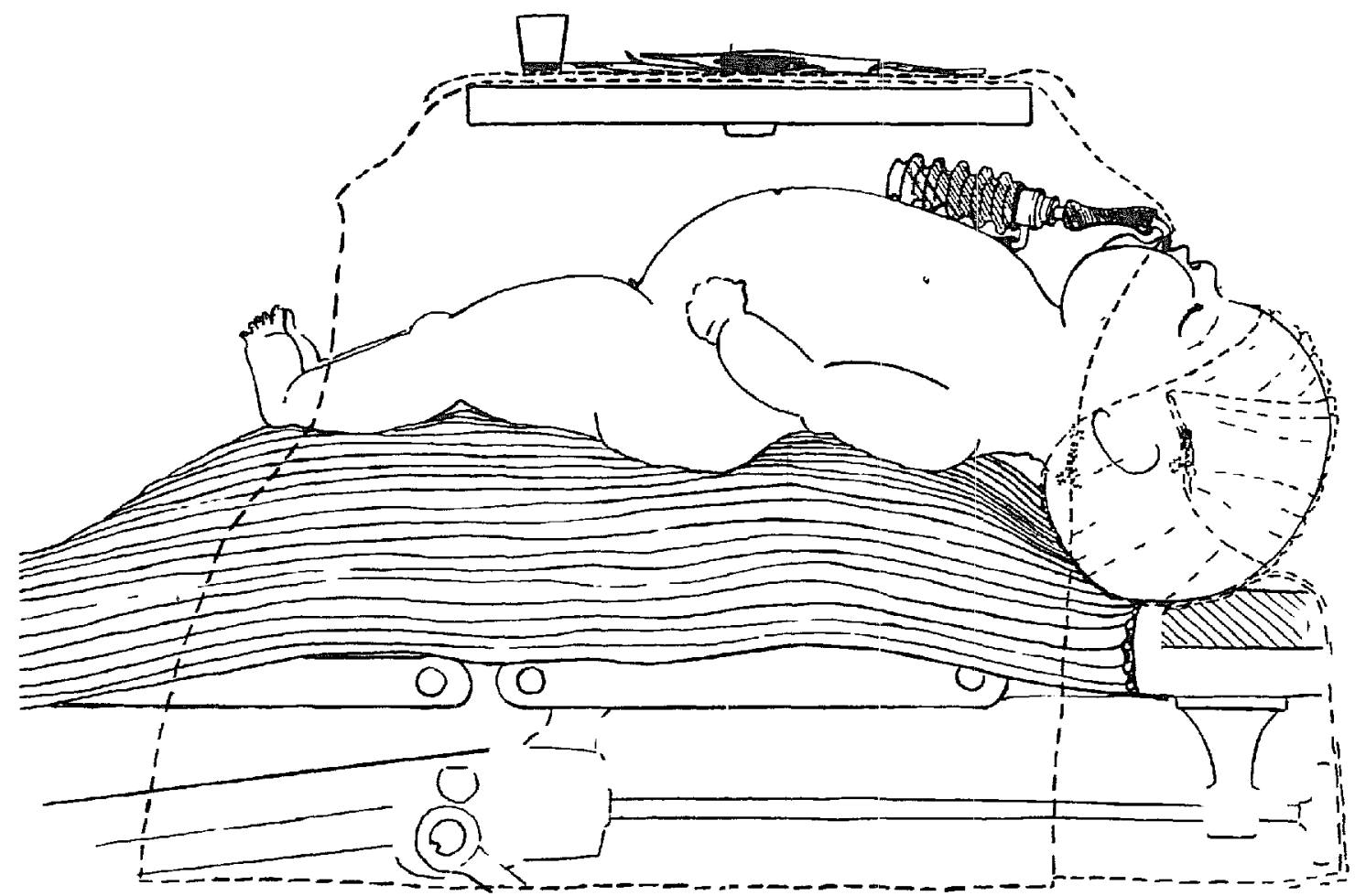

Figure 2. Position of infant on the table, intubated, with Ayre's T-piece. The Mayo table is shown and the dotted line indicates the site of the drapes. 
Usually within a matter of five minutes the body temperature begins to fall and at this point rewarming of the blanket to $90^{\circ} \mathrm{F}$ is begun. Withir the next 5 to 10 minutes the body temperature tends to reach $93^{\circ} \mathrm{F}$. The operation is then begun and anaesthesia is changed over to equal proportions of nitrous oxide and oxygen. The body temperature is maintained in the neighbourhood of $92^{\circ} \mathrm{F}$; respirations at that temperature are quiet and slow; the skin is pale pink and dry and pulse tends to be slow. With this technique it has been found that the incision of the tissues is practically bloodless and the only bleeding is from the coronary vessels and from vessels in the nasal floor, all of which are immediately secured. Blood loss is negligible. Towards the end of the operation the blanket is heated, raising the body temperature to about $95^{\circ} \mathrm{F}$. The baby will awake immediately upon withdrawal of the anaesthetic mixture. The child is then transferred to the recovery room wrrapped on warm blankets and has its first feeding within half an hour of the end of operation. Essentially the same technique is used for repair of both cleft lip and palate.

Both fall and return of body temperature are very rapid in small infants because the heat-regulating mechanism is still labile; it is most important to realize this tact in order to prevent undue depression of temperature. We make it a rule to start an intravenous infusion before the operation is begun in order to have access to a vein for any possible medication. The degree of hypothermia used produces no cardiac irregularities.

\section{SUMMARY}

Moderate hypothermia to $93^{\circ} \mathrm{F}$ produced by means of surface cooling has been used with success in cleft lip and palate operations in infan s, the risk of hyperpyrexia in these cases being thereby removed. The bleecing in the operative field is reduced to a degree which greatly facilitates surgery and reduces over-all operating time. Anaesthesia is maintained through an endotracheal tube by means of the Ayre's T-piece. Very little general anaesthesia is required, once body temperature has been lowered. This technique allows for minimum interference in the feeding schedule, as anaesthesia is induced 3 hours after the last feeding and the total anaesthesia time is not allowed to last much over 1 hour. Children are immediately awake on rewarming and are able to talk and retain their feeding.

\section{RÉSIJMÉ}

L'emploi de la méthode d'hypothermie légère à $93^{\circ} \mathrm{F}$, obtenue par refroidissement périphérique, s'est avéré un succès dans les interv'entions pour bec-delièvre et gueule-de-loup chez les enfants; on élimine ainsi le danger que pose l'hyperthermie dans ces cas. On diminue, en plus, le saignement au niveau du champ opératoire à un degré suffisant pour faciliter l'acte chirurgical et raccourcir le temps de lintervention. Pour l'anesthésie, on se sert d'un tube endotrachéal attaché à un tube d'Ayre en $T$. On constate une diminution importante de la quantité des anesthésiques généraux à administrer, une fois la température du corps abaissée. Cette technique offre l'avantage de n'apporter 
cue des changements minimes à l'horaire des boires, puísqu'on commence lanesthésie 3 heures après le dernier boire et que le temps total d'anesthésie dépasse rarement 1 heure. Dès qu'ils retrouvent leur température normale, les enfants sont parfaitement réveillés, peuvent parler et garder leur boire.

\section{REFERENCES}

1. ECKenhoff, ]. E. Some Anatomical Considerations of the Infant Larynx Influencing Endotracheal Anaesthesia Anesthesiology 12: 401 (1951).

2. Stephen, C. R., \& Slater, H. M. Basic Principles of Paediatric Anaesthesia. Canad. M. A. J., 60: 566 (1949).

3 Woodfinld-Davies, H. Modern Practice in Anaesthesia. 2nd ed., London. Butterworth (1954).

4. Scotr, D. L Some Useful Anaesthetc Accessories. Anaesthesia 5. 217 (1950).

5. Davies, R. M. A Modification of the DotT Gag Lancet 2635 (1954). 